\title{
Prosthetic Intimacies: Television, Performance Studies, and the Makings of (a) Life
}

\section{Nick Salvato}

\section{Five Uneasy Pieces}

In a recent article on television fandom, Nick Couldry advocates to fellow scholars:

[F]andom research needs a theoretical flexibility to match the phenomenological complexity of much fan experience. Instead of a "unified" model that privileges one framework of interpretation (psychological, sociological, economic, textual, spatial), we need perhaps a toolkit from which, when faced with particular fan experiences, we can draw on any or all of these frameworks. ${ }^{1}$

Adopting Couldry's thoughtful recommendations for the study of television fandom - and extending them to the study of television more generally- I would ask, is not the "toolkit" that Couldry imagines already provided by the methodologies of performance studies? And does not his declining to name the toolkit explicitly as a performance studies approach suggest the extent to which scholars still fail to think capaciously across disciplinary formations like television studies and performance studies, even when one or the other (or both) of those disciplinary formations has positioned itself as an inter-discipline, if not an antidiscipline? To ask these questions is to translate another, more idiosyncratic question with which I have been tarrying as I contemplate performance studies' potential contributions to television studies: What insights might profitably emerge from considering together the following five, uneasy pieces of evidence?

1. In an episode of the NBC sitcom 30 Rock, "Generalissimo," Jack Donaghy (Alec Baldwin) discovers the source of his girlfriend's grandmother's otherwise unaccountable animus toward him: he looks exactly like the actor Hector Moreda (Alec Baldwin), who plays the arch-villain on the telenovela, Los Amantes Clandestinos, a favorite of the grandmother, Conception (Teresa Yanque). Eager to secure Concepcion's affections, Donaghy wields his power as an executive at a fictional approximation of NBC and colludes with Moreda to transform the

\footnotetext{
Nick Salvato is Assistant Professor of theatre and a member of the graduate faculty of English at Cornell University. His first book, Uncloseting Drama: American Modernism and Queer Performance, is forthcoming from Yale University Press in fall 2010, as part of the series Yale Studies in English. He has published articles in such journals as Modern Drama, TDR: The Drama Review, and Theatre Journal.
} 
arch-villain, known as El Generalissimo, from "pure evil" into "everything that [Concepcion] desire[s]."2

2. In response to a survey about television viewing habits and practices of everyday life, a friend writes to me:

I use jokes from sitcoms to make friends and influence people. In 'real life' I am not all that funny. However, I am frequently described as such mainly because I steal jokes from Will \& Grace and use them in everyday conversation ALL THE TIME. And I play them off like they're my own. Sometimes I'll confess this habit to significant others (honestly - I do it so much, it doesn't seem fair that I get all the credit); however, hardly anyone ever believes me and if they do - I am quite certain they fail to recognize the magnitude of my deception. I have so deeply succumbed to this behavior, that I've purchased every DVD of the show and I watch at least two episodes / day (though I've seen them all several times) just to keep my game tight. I obviously have a second set of copies of seasons 6 and 7 (the funniest seasons) that I keep at work to watch when inspiration wanes. I have stolen so many jokes over so many years, I'm a bit unclear where my humor stops and where their writing staff begins. While this habit makes me feel like a less-than-totally-genuine human being, I can't say I beat myself up all that bad[ly] for my rampant conversational plagiarism. Will, Jack, Karen and Grace (I'm quite sure) would all appreciate it. ${ }^{3}$

3. Responding to the same survey, a stranger begins by declaring emphatically, "I do not own a TV and do not watch TV," then modifies this claim:

I watch so little TV, and then [on] the occasion in recent years when I did (watch all of Battlestar Galactica) I was very surprised by how much images of the show and characters in it subsumed my thinking. I think I walked around for a week afterwards with my head full of it, running through different scenes, being genuinely annoyed by what happened with the characters. It was striking because I watch no TV, and so really noticed the difference. I felt that it crowded out other thoughts in my head, and was slightly alarmed by the whole thing. Despite this alarm, however, if given the chance I would have sat down and watched another three seasons with all the glee of a real addict. ${ }^{4}$ 
4. Claire Parnet conducted an extended, filmed interview with philosopher Gilles Deleuze, L'Abécédaire de Gilles Deleuze, segments of which were broadcast by the European public-service television channel Arté in 1994 and one crucial moment of which is described thickly by scholar Charles J. Stivale in a book-length study of the interview:

Deleuze's long reflection on friendship in ' $\mathrm{F}$ as in Fidelity' . . . reveals [his] affective connection [to Parnet]. His definition of friendship amuses Parnet, who uses it as a transition point to a different topic.... Deleuze says that the charm that people reveal only comes through their madness (folie), through the side of someone that shows they're a bit unhinged. He maintains that if you can't grasp the small trace of madness in someone, you can't be their friend. But if you grasp that small point of someone's insanity (démence), the point where they are afraid or even happy, that point of madness is the very source of their charm. ${ }^{5}$

5. In an article in The New Yorker about solitary confinement in American prisons, Atul Gawande relates the experience of an inmate whom he has interviewed:

After a few months without regular social contact ..., his experience proved no different from that of . . P.O.W.s or hostages, or the majority of isolated prisoners whom researchers have studied: he started to lose his mind. He talked to himself. He paced back and forth compulsively, shuffling along the same six-foot path for hours on end. Soon, he was having panic attacks [and] screaming for help. He hallucinated that the colors on the walls were changing. He became enraged by routine noises - the sound of doors opening as the guards made their hourly checks, the sounds of inmates in nearby cells. After a year or so, he was hearing voices on the television talking directly to him. He put the television under his bed, and rarely took it out again. ${ }^{6}$

I nominate these items as five uneasy pieces of evidence (in part) because of the uneasiness that some critics would have about assessing-alongside, with, and through each other-such complexly diverse data as the "text" of a television episode, a survey response from a friend, a survey response from a stranger, a passage from a scholarly book, and a passage from a popular journalistic article. In response to the implicit question "Evidence of what?" I submit that the constellation of these five items may demonstrate the methodological principle, arguably central to performance studies, that there is a useful way to interpret such kinds of 
information as powerfully imbricated species (descriptions, or even enactments) of performance. Of course, care must be taken in refusing to flatten the contours of or elide the important distinctions among the performances thus constellated, even as the claim is made that they belong on the same spectrum of analyzable activity. And when such care is indeed taken, Couldry's toolkit metaphor becomes a very apt, if originally unintended, one with which to describe the performance studies model: a cache of instruments with different but related qualities is used to perform - to "do, carry out ... [en] act"7 — the work of analysis. Perhaps just as importantly, as I intimated above, the five objects, likewise different but related, on which that analytical work will be focused here are themselves examples of ways in which one might perform: each object is not discrete or contained, but is rather the processual and relational unfolding of 'doings' or 'acts' in time and over space. 'Television,' then, could be shorthand for just one such temporal and spatial field of action, unfolding, and relationality.

As the analysis of that field moves forward, a related question may be more difficult to answer: "Evidence for what?" On the one hand, each of the performances cited above seems to beckon toward a different meditation about television. "Generalissimo" could invite speculation about the shifting status of putatively 'hybrid media forms' like the telenovela in a moment of cultural imperialism's own reconfiguration as a hybridized formation. ${ }^{8}$ The first survey response that I cite calls perhaps for an engagement with Janice Radway's notion of interpersonated performance, "a performance that involves the sometimes vocal, sometimes silent, sometimes communal, sometimes private mobilization of the words of another." The tensions and contradictions in the second cited survey response remind us of the continuing relevance of Ien Ang's now classic assertion that "[w] hat people say or write about their experiences, preferences, habits, etc., cannot be taken entirely at face value, for in the routine of daily life they do not demand rational consciousness ... we must search for what is behind the explicitly written, for the presuppositions and accepted attitudes concealed within them." ${ }^{10}$ Stivale's written, English paraphrase of a filmed French interview that was not originally intended for televisual broadcast, that only appeared evanescently on the air, and that is now available for re-viewing on DVD begs the question, "What is the 'television' of television studies," a question foregrounded in such investigations as Lynne Joyrich's parsing of the "epistemology of the console." And the wrenching anecdote that Gawande shares about a prisoner's relationship to television in solitary confinement indicates the necessity of thinking about the spatial specificities of television spectatorship's sites, an issue made central in the work of such scholars as Anna McCarthy and Lisa Parks. ${ }^{12}$ All of these separable lines of inquiry are important, and each one will accordingly receive some treatment, whether direct or oblique, in the multipronged argument that follows.

On the other hand, I am also, and more chiefly, interested in the common cluster 
of problematics that emerges when we consider how each of these performances may point in more or less the same direction. While a number of answers to this proposition may suggest themselves, I assemble this suite of performances to discuss phenomena, perhaps preponderantly common to television as a medium, for which I would like to coin the rubric prosthetic intimacies and through which rubric I would like to unfold a set of yoked interpretations of the performances in question, as well as of other, related ones. In short, prosthetic intimacies are subjective experiences of proximity and affectivity made possible and legible by confrontations with technics that would seem distinguishable from the subjects confronting them, but that rather contribute indissociably to the performative constitution of those subjects. An exploration of these intimacies' contingencies will clarify not only relations of power and degrees of agency prevalent in post-modernity, but also the contours of prevailing projects of life-making: their conditions, pleasures, and limits. Such an exploration will also clarify how the tools in the performance studies kit, as described above, may themselves serve as prostheses for intimate articulations, even as the articulations of intimacy are revealed, often, to be just as uneasy in their making and uneasy-making in their apprehension as (or as in) my framing pieces of evidence.

\section{Synthetics, Prosthetics, and Publics}

The field of television studies is no stranger to the concept of intimacy. Indeed, a substantial body of work from roughly the first two meaningful decades of the discipline has focused on intimacy, the collective and cumulative understanding of which is well summarized in a recent essay by Gary R. Edgerton:

The scholarly literature on television has established intimacy and immediacy (among other aesthetics) as intrinsic properties of the medium .... In the case of intimacy, for instance, the confines of the relatively smaller TV screen which is typically watched in the privacy of the home environment have long ago resulted in an evident preference for intimate shot types (i.e. primarily close-ups and medium shots), fashioning most fictional and non-fictional historical portrayals in the style of personal dramas or melodramas played out between a manageable number of protagonists and antagonists. When successful, audiences closely identify with the historical 'actors' and stories being presented, and, likewise, respond in intimate ways in the privacy of their own homes. ${ }^{13}$

Of course, such a schematic account of televisual intimacy, hinged on ostensibly transparent and self-evident notions of closeness, privacy, and identification, 
can be-and has been - subjected to rigorous scrutiny and critique. Far from necessarily establishing closeness with viewers, television, it has been argued, may succeed rather in distancing audiences from its spectacles. As Nick Couldry observes, "the paradox of a phenomenological 'nearness' . . . is inseparable from a practical and material distance from [televisual] production. . . . [T] his feature has generated contrasting assessments: some argue that media events remain too distant for moral engagement, while others fear that [television] brings those events trivially close."14 Further, the related ideas that television is only or even primarily watched in the 'privacy' of the home - and that the home is a site distinct, separable, and safely preserved from public space-have been punctured by accounts of both television's and the home's complex publicities. ${ }^{15}$ As for identification, it may often be a misnomer for "the back and forth operations of recognition, misrecognition, [and] simplification . . . that characterize television viewing wherein we imagine that we ourselves or versions of our lives are 'on' TV." 16 And yet, despite these trenchant contestations, a working understanding of intimacy, essentially unchanged from those obtaining chiefly in the 1970s and 1980s, persists in recent work on the subject. In her 2008 book Reality Television, Affect and Intimacy: Reality Matters (part of the prominent "Language, Discourse, Society" series), Misha Kavka, for instance, writes of television as a "technology of intimacy" that "functions by drawing viewers close," that promotes " getting to know other people," "and that "involves the amplification of everyday familiarity to produce a level of hyperfamiliarity." $"$ This uncritical reproduction of an earlier era's truisms about televisual intimacy fails, curiously, to consider such alternative possibilities as viewers' radical estrangement from what and whom they see on television, the attrition of everyday familiarity, and the concomitant production of the 'hypofamiliar,' or the deformation of the familiar in the very guise of familiarity.

In another curious omission, Kavka, like so many critics who take for granted the meanings of intimacy, never proffers an explicit definition of the term. Tellingly, the $O E D$ registers a productive tension inherent to intimacy, as the word "intimate" not only signifies what (or who) is "inmost," "closely personal," "closely connected by friendship or personal knowledge," and "very familiar," but also may be used, powerfully and evocatively, to describe "a theatrical performance, [especially] a revue[,] that aims at establishing familiar and friendly relations with the audience[;] [a]lso of a theatre itself." ${ }^{\prime 18}$ Inscribed, then, at the very heart of the modern conception of intimacy (for the intimate theatre is an invention of the late nineteenth and early twentieth centuries) is a sense of intimacy's paradoxical theatricality, or at least a sense of intimacy's capacity, fundamental to its iterations in modernity and postmodernity, for simulation or extenuation in and through the theatrical (or, more broadly, the performative). Following the trail of intimacy's simulations, Joseph Roach has written provocatively about what he calls the "synthetic experience" industries, including but not limited to theatre, whose avatars use "the illusion 
of availability" to offer their audiences the satisfactions of "vicariousness." 19 As a complement to Roach's work, I wish to draw attention here not to intimacy's simulations, but to its extenuations - not to its synthetic, but to its prosthetic, coordinates.

To posit an intimate sphere with synthetic or vicarious counterparts is to imagine, implicitly, the (potential) detachability or severance of those counterparts from the intimate sphere whose motions they simulate. But what of the cases in which intimacy is inseparable from its augmentations - in which intimacy is only recognizable as intimacy because of its augmentations, as when "the addition of a syllable to the beginning of a word" (the original, grammatical meaning of prosthesis $)^{20}$ makes a new word whose integrity as a word depends upon the addition? In these cases, the prosthetic, rather than the synthetic, must be intimacy's modifier; for, as Marquard Smith and Joanne Morra have crucially observed, there are many intimate ways in which "the body and technology come into contact with one another and are integrated, fused, reciprocal, and parasitic." Thus, it becomes the critic's task to recognize "exactly how 'the prosthetic' is an integral or 'interconstitutive' part of the 'human"” and to probe "the prospect that the body and prosthesis are already of one another in specific ways that are lived out and experienced through material as well as metaphorical considerations." ${ }^{21}$ Where the material considerations of which Smith and Morra write are manifest in televisual experience, we might look, most obviously, to the remote control as one of the body's major prostheses, as have such critics as Thomas Elsaesser and Jaap Kooijman in their theoretical reflections on "zapping." 22 We might also think of the remote-zapping hand as the keyboard-tapping one, as more and more people watch television programming on their computers. But to bring into focus the metaphorical considerations of which Smith and Morra also write - and to insist on the mutual impaction of the material and the metaphorical-I reflect here more expansively on the ways in which the field of television as such, with its flows and segmentations, and from its production and distribution through its reception and citation, may be understood as a field of prosthetic intimacies: that is, intimacies marked simultaneously and paradoxically by surplus (that the televisual prosthesis provides) and lack (that the provision of the televisual prosthesis always-already presupposes), by adequation and incommensurability.

Intimacy's lacks and incommensurabilities may be familiar to us from the prominent work of Lauren Berlant, whose theory of intimate publics clarifies the ways in which "contemporary nationalist ideology recognizes a public good only in a particularly constricted nation of simultaneously lived private worlds"; as a corollary, Berlant laments that "the use of intimacy as a distraction from critical engagement with a general matrix of ordinary hard hierarchy actually impairs discussions of intimacy itself, in its broader social contexts." ${ }^{23}$ Berlant's work is indispensable to contemporary thinking about intimacy, but in her critical, 
passionate emphasis on the ideological injunction for subjects to live simultaneously but privately (and in her deliberate, historically informed elision of intimacy and privacy), she often neglects the very "discussions of intimacy itself, in its broader social contexts" that nationalist - and other kinds of - ideology would seek to occlude and that might preserve a space for a carefully and sometimes positive, if qualified, valuation of intimacy. By shifting registers and inflection from public intimacies to prosthetic intimacies, I aim to consider, at least in part, the nodes at which rich subjectivities may be informed as well as or instead of deformed, sustained as well as or instead of malnourished, by encounters with and eruptions through television. Importantly, Berlant is also interested in television, and it is no coincidence that a central lineament of her argument about the intimate public sphere emerges from an essay featuring a close reading of an episode of The Simpsons, "Mr. Lisa Goes to Washington." Reading, against the grain, Berlant's interpretation of The Simpsons may measure well the further distance that I intend to travel from her work in my elaboration of the concept of prosthetic intimacies. And this reading will be, so to speak, an extended one: a sixth uneasy piece of evidence, a fugitive surplus with which I augment, prosthetically, the opening gambit of this essay. Working with and through Berlant's argument is a process that I deem not only necessary for clarifying further the stakes of thinking about prosthetic intimacies, but also performatively apt for vivifying the stakes of thinking prosthetically about intimacies - a vivification enacted by this very critical gesture.

Berlant frames her discussion of Lisa Simpson as a meditation on the "Smart Girl Citizen" whose "intelligence is established as superior to the jingoism of ordinary Americans;" she then reveals dramatically, and upon closer examination of Lisa's characterization in "Mr. Lisa," that "Lisa [is] not that smart" after all because of the ways in which she fails to withstand "the shock of national power [that] television-style media produce for her" and to critique fully "the waste and excess that [dominate] the scene of patriotism" - in short, to read the intimate public sphere as savvily (and savagely) as Berlant herself does. If I risk here a (mis) identification of Berlant and Lisa, I do so in order to make explicit the embedded ways in which Berlant herself risks - but disavows - this same (mis)identification. The (mis)identification emerges most clearly, if briefly, in a passage in the essay in which Berlant writes of Lisa "seek[ing, at a competition in Washington and from other smart schoolchildren,] an affirmation of her idealized self-image: learning early that the reason people go to national conferences is to find confirming images of their ideal selves. ${ }^{24}$ How could we read these words and fail to think of Berlant, like Lisa, as one of those people who go to national conferences, given the fact that the book of essays of which this one is a part begins with an anecdote about a public lecture at which "a colleague said, 'I really admired your thinking, but-I hate your archive""? And, given the fact that Berlant adds editorially, "I loved this moment," ${ }^{25}$ how could we fail, further, to view Berlant as either identifying with 
Lisa (Berlant's image of her ideal self, as an intellectual who relishes provoking her colleagues, is confirmed by her colleague's combination of admiration and hatred, which she loves), or distancing herself from Lisa (more simply, Berlant does not seek, with servility, her peers' approval) or, more likely, some complex combination of the two? The way in which Berlant's (mis)identification with Lisa contains within it the seeds of an equivocal disidentification has significant rhetorical power: we, too, are asked implicitly to (mis)identify with Lisa (smart kids, all?), so that we will feel the full impact (another kind of 'smart') of Berlant's unequivocal, ultimate disidentification when she announces, and seems to savor announcing, that "Lisa [is] not that smart," as it turns out. For all of Berlant's suspicion of (and barely sublimated crankiness about) affect's ability to forestall critical inquiry, her own critical argument depends - intimately — upon affective strategies: through the mediation of the page, she constructs a prosthetic intimacy with her close readers that, we would not be outrageously overreaching to suppose, she takes a surreptitious pleasure in finally refusing, in the name of a rational discourse putatively purged of such affect (but, as I am suggesting, suffused with it nonetheless).

To embroider this reading with a consideration of television's specificity as a medium, I would add that Berlant's claim that "Lisa [is] not that smart" depends upon a disingenuous account of how television in general, and The Simpsons in particular, work on audiences. To make the claim, Berlant must linger on Lisa's own seemingly amnesiac claim about government, near the end of an episode of the program full of Washington backroom-dealing and hypocrisy, that " $[\mathrm{t}] \mathrm{he}$ system works!"26 - and Berlant must further believe that Lisa believes this claim. Bracketing for a moment the imputation of agency to a fictional character, I question Berlant's notion that Lisa is not in on the joke and that the episode's cynical and dismissive view of the system working somehow escapes and exceeds her. In order to advance such a reading, Berlant must ignore a fundamental aspect of the way in which The Simpsons hails us as viewers, with an address to which we respond so effortlessly that the address's artificial construction has been naturalized. Because the program is a hybrid of the domestic sitcom and the political satire, the characters must operate, with divided natures, in the two registers of 'domestic time/space' and 'satirical time/space.' ${ }^{27}$ The Lisa who claims, with ostensible naïveté, that the system works is, if you like, a satirical prop, a pedestrian punch-line deliverer whose flatness is radically disconnected from the emotionally nuanced Lisa in whose domestic characterization we are invited to invest. The convention of switching between these two codes has been so consistently used on The Simpsons over so many years that we may scarcely notice its deployment.

Berlant also suppresses the complication that we don't judge Lisa's smartness, if we are so inclined to judge, on the basis of one line in one episode, but rather through the gradual accretion of many moments in many episodes, not all of which are likely to be watched sequentially or with anything like a consciousness of 
progress (indeed, The Simpsons itself refuses an overarching narrative of progress by permanently and knowingly arresting its animated characters' ages). The accretive Lisa, who does not exactly develop but who does nevertheless multiply, has been endowed with ample and multifaceted intelligence (including a highly developed emotional intelligence). If Berlant wished to assuage her evident disappointment in Lisa's onetime avowal of the system, to recalibrate her (mis)identification with Lisa, and to extend her prosthetic intimacy with the character (but she does not appear so to wish), she might consult a host of other episodes. One of particular sophistication is the Emmy Award-winning "HOMR," in which Homer, having had a decades-old crayon surgically dislodged from his brain, enjoys a sudden intelligence vastly superior to that of his peers, as well as a newfound appreciation for Lisa's own extraordinary intelligence. Ultimately, the pressures of alienation and "othering" produced by his intellectual pursuits lead Homer to stick the crayon back in his brain and to return to a state of blissful idiocy and camaraderie with the residents of Springfield, but not before he writes a note of consolation to the daughter with whom he will no longer be able to sustain the bond of shared intellection: "Lisa: I'm taking the coward's way out. But before I do, I just wanted to say being smart made me appreciate just how amazing you really are. ${ }^{28} \mathrm{I}$ am interested in this episode of The Simpsons less precisely because it ends with a scene of fraught prosthetic intimacy, which is negotiated by a note with no bearer and which beckons prosthetically for our own fraught and intimate responses, than because it begins meta-formally, locating the Simpsons at an animation festival where a pre-operative Homer declares, "Animation is so great! It's way better than ... whatever the alternative is." Through a series of intricate convolutions of plot, the episode's affectively charged final scene is framed as the inevitable conclusion of a dramatic arc that begins with a recursive opening scene about cartoons (a structural feat that puzzles, troubles, or simply irritates many of the most lucid online commentators at The Simpsons Archive ${ }^{29}$ ). The structural logic of the episode suggests, then, that whatever intimacy is generated as or by the content of The Simpsons is prosthetically inseparable from its form as a cartoon (there is no "alternative"), just as Homer's responses to stimuli are prosthetically inseparable from the crayon in his cranium (an addition that creates a deficiency), and just as audiences' responses to the program are prosthetically inseparable from the specific effects that television, as a medium, is poised to produce. Meta-television of the sort manifested in "HOMR" is particularly well-suited to illuminate such implications and stakes of prosthetic intimacies; and with these implications and stakes in mind, I alight on a related example of meta-television: "Generalissimo," that first piece of "uneasy" evidence. 


\section{Five Easier Pieces}

In an important, recent essay on television, queer theory, and cultural studies methodology, Amy Villarejo cautions against close readings of televisual "texts" that are not grounded in a thoroughgoing consideration of the materiality of industrial practices. With an eye trained particularly on the televisual genesis of queer content, she juxtaposes this kind of admirably informed close reading with a woefully "simple or self-evident reading of what is, after all, industrially produced sexual rhetoric, queerness literally brought to you by Sony or GE (General Electric). Cultural studies work never loses sight of the horizon of the textual in the social." Indeed, Villarejo foregrounds the social and the industrial in such a way that she implies the potential obsolescence of close textual reading of any sort, as she herself refuses explicitly — at least in this essay — to offer any "reading of some show you love or some incredibly-hip-show-you've-never-heard-of-butwill-pledge-forevermore-to-watch-faithfully." ${ }^{\prime 30}$ Bearing in mind this judicious critical approach, I want, nevertheless, to risk a close reading of an episode of 30 Rock, precisely because the episode - and the series - positions itself as a species of meta-television whose scrutiny is fixed on the very industrial practices to which Villarejo also labors to bring our critical attention. Matters of crucial interpretive concern include how a televisual text fictionalizes the economic and material context of its own production; how this fictionalization simultaneously brings into relief and obscures the realities of such production; how we assess the consonances and the gaps between the fiction and its real counterpart; and how all of these factors dovetail with a consideration of prosthetic intimacies.

Created by Tina Fey, who also stars in the show as TV writer Liz Lemon, 30 Rock is a backstage drama that discloses to us the daily operations of Lemon, a head writer (like Fey herself on 30 Rock), and her staff at the live sketch comedy series The Girly Show (a fictional equivalent of Saturday Night Live). It features the daily manipulations of the narcissistic stars of The Girly Show (one of whom, Tracy Jordan, is played by Tracy Morgan, who was formerly a star of $S N L$ ) and the daily machinations of charmingly Machiavellian Jack Donaghy, a network executive of programming at "NBC" (an approximation of the network on which 30 Rock actually airs and which, like the site of NBC Studios at 30 Rockefeller Plaza, retains its real name on the series). It is in this highly self-reflexive context that Jack seeks, in "Generalissimo," to renovate the plot and characterizations of Los Amantes Clandestinos in order to use the renovation, prosthetically, to secure greater intimacy with Concepcion, the matriarchal abuela without whose approval, he fears, his romantic relationship with her granddaughter Elisa (Salma Hayek) will be irrevocably compromised. Of course, because of his power as a high-ranking network executive, the televisual prosthesis that Jack wields, in the name of intimacy, may be more specifically understood as a televisual phallus of a conspicuous and rarefied sort. In response to the problem that "[t]wo hours a day, five days a week, 
Hector Moreda and the Generalissimo are poisoning Elisa's grandmother against me," Jack takes action. He announces proudly to Lemon (as he calls her) and Elisa, "This morning, Telemundo, which is owned by Sheinhardt Industries, purchased Los Amantes ... And now, I own it"- to which Elisa responds, "Isn't that romantic?" Sheinhardt Industries stands here for General Electric, the behemoth that owns NBC Universal as well, in fact, as Telemundo. That a telenovela's ownership might be subject to a lone executive's personal whims is indeed "romantic," in the sense that it is fantastic, but the fantasy bodies forth vividly the extent to which the world's largest company typically operates without discernible constraint. Even when Jack's initial scheme, whereby Lemon will be made head writer of Los Amantes and kill off the Generalissimo, fails because of Moreda's last-minute rewrites (in an attempt to save his job), Jack remains undeterred and colludes with Moreda, in an even better scheme (more advantageously capitalizing on the prosthetically intimate), to re-envision the murderous and rapacious Generalissimo as a gentle lover who courts an old Puerto Rican woman not unlike Concepcion. El Generalissimo, whose very name evokes aurally the absent presence of General Electric, is a character who may change from simplistically evil to simplistically good, but what remains constant across the characterization is his representation as a man who gets whatever he wants (including, especially, the old woman). He could not be a more suitable mirror for Jack, who likewise wins over Concepcion with the changes that he makes to her favorite show.

At the same time, that mirror is, however, one in which Lemon tragicomically misrecognizes herself. As Elisa feeds her information about the Generalissimo's back-story in order to fuel her new writing assignment, Lemon is inspired to ape his villainous schemes in the service of seducing her hot new neighbor, Drew (Jon Hamm), whose mail has been errantly delivered to her apartment. (In an episode shot through with messages about media's capacities to engender prosthetic intimacies, it is important that Lemon wants to seduce her neighbor because she likes what she learns, from illegally opening his mail, about his Netflix movie choices.) As Lemon's scheme inevitably backfires, her subplot is figured as a moral lesson about the perils of over-identification, moving Lemon from her initial insistence, "I am not the Generalissimo" (she denies her capacity for evil even as she attempts to model her behavior on his), to her final, horrified realization, "I am the Generalissimo" (when she inadvertently "roofies" Drew, who deduces, before losing consciousness, that she has been reading his mail). But the superficial logic of this progression belies the deeper meaning of the episode. Indeed, Lemon has it right the first time: she is not the Generalissimo, nor is she Jack, and she cannot, like them, execute fancifully unethical strategies to get whatever she wants. Her misfit in this role is underscored visually by a rapid cut from the disastrous interior of her apartment, where Drew is unconscious on the floor and a fire has erupted from a fondue mishap, to a pristine exterior shot of the phallic GE Building at 30 Rockefeller Plaza, which 
stands synecdochically for Jack's corporate power.

But Lemon, as the head writer of a successful network television show, has a great deal of power, too, an obstacle to her depiction as a bumbler that this episode of 30 Rock, and the series more generally, take great pains to qualify or obscure, so that "average" viewers (bumblers, all?) may more easily identify with Lemon. Tellingly, when, at the end of the episode, she wins over Drew despite her earlier, bad behavior, she benefits not from what she writes but from what she watches on television to secure a prosthetic intimacy with him. As he stands at the threshold of her apartment (from which vantage point they can both see the screen of a television set, one or another of which is ubiquitous on this series), she issues an awkward and vulnerable apology and says of the prospect of trying to date again, "Weirder things have happened, right?" - and then, as if to corroborate her sentiment, the television emits something that is indeed much weirder: the spectacle of a news conference at which Tracy Jordan announces that Lehman Brothers will reopen under his management. "Okay, it's a date," Drew shrugs (there is no escaping the sphere of television or denying its motions), providing Lemon - and 30 Rock's audience - the satisfaction that the fragile and contingent coupling of her emotional accessibility and her television viewership, rather than her privilege as an agent of industrial production, will secure her the intimacy that she "really" wants. Just as Lemon misrecognizes herself in the Generalissimo, so, too, are we invited to misrecognize ourselves in her and to associate with her representation the complex of our desires and hopes; the show's open acknowledgment of the former misrecognition works to camouflage the latter one.

Other important (and intimate) stakes of television viewership are also being acknowledged and camouflaged in this episode of 30 Rock, specifically through the representation of Concepcion, whose age, class, gender, and ethnicity make her an extremely unlikely candidate to have the ear of a network executive, either at the real NBC or at its fictional proxy. Once she has it, she enacts a deliberately overdone stereotype and tempers her praise for Jack's changes to Los Amantes with the stern question, "What are you going to do about the NBC news? It's too sad." Jack's response trades equally in stereotypes: at the very end of the episode, we see (on Lemon's television, and after Tracy's press conference) Matt Lauer, who concludes a newscast thus: "And now, to lighten things up, some pictures of beautiful Latin babies and the music of Tito Puente." He then turns to a presumed behind-thecamera interlocutor and says, "Jack, this is ridiculous." It is ridiculous. 30 Rock, as I have argued elsewhere of similarly styled cultural productions, "highlight[s] and [critiques] . . . racism by overdoing rather than muting" racist gestures. ${ }^{31}$ It uses this strategy to acknowledge the series' own limitations: the show, like the fantastic NBC newscast, will never incorporate the input of a real subject "like" the citationally simplified and caricatured Concepcion-a subject whose desires remain unknowable to the makers of the series and whose prospects for prosthetic 
intimacies as rosy as Concepcion's (or Lemon's, or Jack's) are not apparent or, very likely, tenable. And yet the recognition of these limitations entails a further erasure, one effected through sound ${ }^{32}$ as Tito Puente's music moves among different diegetic and non-diegetic registers and scores not only the end of the fictional NBC broadcast, but also Lemon's date-making with Drew and the closing credits of the episode of 30 Rock itself. What we see is Matt Lauer's breaking of the frame and admission of the ridiculous paucity of Jack's vision, but what we hear is harmony: Latinidad's seamlessly coordinated unification of all the show's spaces, and, with that unification, a sonic guarantor of resolution through happy cross-contextual (specifically, cross-cultural) encounters.

As we move from the televisual text to its reception (and ape the musical movement from diegesis to non-diegesis), we see how, in a different but related way, questions of agency and sound also commingle complexly in the first of the two survey responses - chosen from among others - which I quoted at length at the beginning of this essay. The respondent, a friend who has worked, not incidentally, in both the television industry and academia, informs me that nobody believes her sometime admissions that her sense of humor is predicated on her citation of jokes from Will \& Grace. The incredulity with which her confessions are greeted stems, it would seem, from the fact that the jokes that she recycles "sound like" her "own," a direct byproduct of the absolutely blurred line, in the field of prosthetic intimacies, between her subjectivity and the cultural products with which she engages - or, as she puts it, the contestable space "where [her] humor stops and where [the series'] writing staff begins." If the respondent describes that space as one about whose contours and edges she is "unclear," that lack of clarity should not be confused with a lack of agency or a lack of critical discernment. Rather, the survey response foregrounds a bold declaration of agency ("I use jokes from sitcoms to make friends and influence people"), and it is everywhere imbued with the respondent's reflexivity about what I have been tracking as the inseparability of the subject from the prostheses with which she establishes and sustains intimacies. "In 'real life' I am not all that funny," the respondent writes, deploying scare quotes to acknowledge her own vivid sense of the ways in which televisual performance and the performativity of everyday life interpenetrate one another intricately and, indeed, messily. She communicates that sense of interpenetration through a quip, too (and not one cited from Will \& Grace, as it happens), when she says of her mode of self-presentation, "Will, Jack, Karen and Grace (I'm quite sure) would all appreciate it." This quip, aligned with the respondent's earlier use of scare quotes to identify "real life" and her nod to the series' "writing staff," reads as her sly and winking acknowledgment that the characters on the series are representations with nothing like consciousness or subjectivity, even as she invests in those representations as if they were endowed with consciousness and subjectivity-an imaginative practice that has significant stakes for her own life performances. Given 
the respondent's self-described encyclopedic knowledge of the series, I wonder, too, whether this statement about its main characters may contain an embedded allusion to an episode of the show, "No Sex 'n' the City," in which Jack (Sean Hayes) and Karen (Megan Mullally) lament the fact that all three of their favorite television series (Frasier, Friends, and Sex and the City) are simultaneously ending, leaving Jack and Karen with the daunting task of "find[ing] something else to talk about." ${ }^{\prime 3}$ Another prominent example of the meta-televisual exploits that I have been tracking, the episode positions Jack and Karen, in line with Roach's thinking, as consumers of vicariousness who are alarmed by the prospect that they may have to forego synthetic experiences and "go out and have life experiences of their own, then get together later and discuss them. You know, like the people on TV do." In contradistinction, the survey respondent draws no tidy line between synthetic experiences and "life experiences" and admits of no a priori self, distinguishable from the field of television, who would enjoy such life experiences, somehow unaffected by the televisual prosthesis.

A stymied effort to draw that very line preoccupies the second survey respondent. Indeed, the first respondent's capacity for critical reflexivity is not evident in the second survey response, which is, rather, striking for its array of contradictions, the rhetorical unfolding of which does not register as considered or controlled. That rhetorical lack of control reflects the ways in which the respondent figures his relationship to the characters on Battlestar Galactica as unbidden and uncontrollable: "I think I walked around for a week . . . with my head full of [the series], running through different scenes, being genuinely annoyed by what happened with the characters. . . I felt that it crowded out other thoughts in my head, and was slightly alarmed by the whole thing." What is conspicuously absent from this report of alarm is not only a testimony of agency like the one that animates the first respondent's account - an agency whose confident extolling aligns her, curiously enough (and only in highly qualified ways), with Jack Donaghy — but also any notable testimony about an array of relationships with "friends," "significant others," and otherwise "influence[d] people" who populate the first response. Here, prosthetic intimacies emerge with, rather than through, the cast of characters of a television series, whose travails seem not to be synthesized as vicarious but, in their processing, to foster cognitively complex, "parasocial" relationships with the characters in question (the kinds of relationships, perhaps, explored by researchers interested in "the emotional space in our Dunbar number," whose reservation for "fictional characters" may "[crowd] out real-life people," ${ }^{34}$ just as Battlestar Galactica "crowded out other thoughts in [the respondent's] head"). Another kind of prosthetic intimacy also emerges, though, from the second survey response - and, for that matter, from the first one. Disseminated online, the survey is itself a prosthesis that I extend, in a performance of solicitation, that invites a particular kind of intimate exchange, as the respondents confess their feelings and 
experiences and, perhaps more importantly, as the nature of their responses blurs the line between the "friend" and the "stranger." On the one hand, friends who are usually "too close" to me are relieved, by the survey's prophylaxis, of the often intense stakes of the dialogic encounter; accordingly, they feel liberated to divulge "overly" personal information. On the other hand, strangers who are usually "too far" away to share such information are now made less anonymous and thus more comfortable making disclosures, as they hypothesize a real, if mediated, subject receiving their responses on the other side of a screen.

Responding to the survey in these ways, the writers perform something like Deleuze's eccentric idea of friendship, as articulated in his interview with Parnet and rehearsed by Stivale: my solicitation prompts, in turn, their solicitations of me to "grasp that small point of [their] insanity (démence), the point where they are afraid or even happy," and thus to recognize that "point of madness" as "the very source of their charm." This kind of "friendly" or intimate transaction is the one that Deleuze performs with and for Parnet — but also, through prosthetic extenuation, for the television viewers of her multi-part interview with him, for DVD viewers of the film, like Stivale, and for readers of Stivale's prose. Elsewhere in his book, Stivale glosses Deleuze's definition of friendship as the constitution of "an indelible effect through our perceiving someone who suits us, who teaches us something, opens us, awakens us, rendering us sensitive to an emission of signs." Clearly, Deleuze teaches and awakens Stivale in this way, and the particular emission of signs to which his "friendship," in these terms, renders Stivale sensitive is another piece of Deleuze's own thinking. His concept of "a life," which is discussed most explicitly in his late essay, "Immanence: A Life," which is distinct from "my life" or "your life," is a small indefinite article meant, as we shall see, to do a large amount of theoretical work. Stivale draws an explicit connection between Deleuzian friendship and "a life" when he quotes Deleuze, in his interview with Parnet as saying, "I . . . want ... just to have imperceptible relationships with imperceptible people, that's what is most beautiful in the world," then glosses these imperceptible relationships as the foundations of " $a$ life [that] may be attained actively only with the greatest effort by artists and writers, by all those who experience ... flights in their creative existences, conceptualizing and understanding $a$ life in its impersonality and imperceptibility." 35

Thinking through the differences between one's life and "a life," Stivale opposes ego to impersonality, as well as "individual lived existence," in its usual and discernible forms, to imperceptibility. ${ }^{36}$ To these oppositions, we might add others, drawn from Deleuze's theorizing in "Immanence: A Life," where "my life," for instance, is constituted in and by my subjectivity, and "a life" inheres in singularity. My life's objects are replaced by a life's virtuals, and my life's moments yield to a life's between-moments. My life's empirical experience is transformed into a life's pure immanence, and my life's actualizations are eclipsed by a life's becomings, 
with the resultant instantiation of "pure power," "complete bliss." ${ }_{37}$ Developing these oppositions, Deleuze makes clear that a life's singularity and immanence are not somehow separable from individual life's subjectivity and experience. Rather, he claims, " $A$ life is everywhere, in all the moments that a given living subject goes through and that are measured by given lived objects: an immanent life carrying with it the events or singularities that are merely actualized in subjects and objects." ${ }^{38}$ An immanent life carries with it the mere stuff of individual life, but in such a way that the stuff, purified, is no longer recognizable as such: is this not a way of saying that "a life" stands in a prosthetic relation to my life, or yours? A life, as prosthesis of personal life, extends that personal life into other imaginative fields - indeed, into another world, according to Stivale, "which cannot be assimilated to everyday banality but one in which, on the contrary, we encounter the final face of Dionysus, and in which resonates the true nature of that profound and that groundlessness which surrounds representation." ${ }^{39}$ To encounter the Dionysian is to confront the wild and ecstatic disorganization of hierarchies — what Deleuze has elsewhere and famously called deterritorialization.

What, then, might be the place of the televisual field in $a$ (deterritorialized) life? Could the subject, becoming imperceptible and having relationships with other imperceptible people, carry with him the prosthetically inflected intimacies of individual life and extend those intimacies, yet more prosthetically, into the zone of immanence? I imagine that zone as one in which the television signals are scrambled, but not short-circuited; in which fragments of the televisual field are not recollected, but erupt - as zigzags or in flashes; in which television, or its content, is not an explicit, discursive subject, but a set of reconfigurable particles in a "molecular network" 40 of intensities. Following this line of flight, I confront, however, the limits of my capacity for such imaginative thinking and remember not only Stivale's explicit assertion that "a life" is achieved, if at all, "with the greatest effort," but also his implicit suggestion that the pursuit of such an achievement is a major luxury (for a class of "artists and writers," perhaps). Homo tantum, as Deleuze designates the (non-) subject pursuing this achievement, ${ }^{41}$ and the life of plenitude, "a life," before him, point in the direction of privileges unavailable toand therefore importantly thought alongside_-homo sacer, and the bare life, or "life exposed to death," that he leads. ${ }^{42}$ Indeed, the related and more modest privilege of describing folie or démence as the source of a friend's charm is not a privilege for the friendless madman, such as the prisoner in solitary confinement, described by Atul Gawande in support of his laudable contention that such confinement is plainly a form of torture, who "[lost] his mind" and "[heard] voices on the television talking directly to him." Quite apart from his total lack of access to "a life," the solitary prisoner cannot even enjoy the ambivalent compensations of more routine forms of life-making - specifically of prosthetic intimacy. For him, the intimacies offered by the closeness of the televisual prosthesis are a menace, a nightmare, from which he 
must distance himself and his bare life, as he "put[s] the television under his bed, and rarely [takes] it out again." In turn, when we "take out" the television, and in order to modify or modulate theoretical reflections about the medium, we must, I think, keep figures like this all-too-distant prisoner in view, in the spirit of the very meaning of television as a system for visioning the faraway, the out of reach.

But how is he best kept in view? Where we first encounter him, in his tiny cell? In the less constrictive places defining his eventual release from prison, when "he lives [alone] ... in a Cambridge efficiency apartment that is about four times larger than [the] cell" and also "works for prisoners' rights at the American Friends Service Committee"? Or, to return to one of the key words with which I framed this essay, in the uneasy time and space between the two, when he was once, during his otherwise solitary confinement, "allowed to have an in-person meeting with his lawyer ... and simply couldn't handle it ... [h] had trouble following both words and hand gestures and couldn't generate them himself'? This third, uneasy moment is the one on which I would like to end, for the relation that it embodies unfolds as a performance, indeed one that could seem ever-so temptingly—cynically? — fit for dramatization on the small screen. And yet the performance is "televisual," in the more capacious sense toward which I have tried to gesture, for its pivotal performer - a much more radical semblable of the would-be performers of intimacy otherwise encountered here, the critic of performance included - is likewise caught between intimacy's failure and its achievement, between communication's potential for misfire and its potential for fulfillment, between "a full-blown panic attack" and something like hope. ${ }^{43}$

\section{Notes}

1. Nick Couldry, "On the Set of The Sopranos: 'Inside' a Fan's Construction of Nearness," Fandom: Identities and Communities in a Mediated World, ed. Jonathan Gray, Cornel Sandvoss, and C. Lee Harrington (New York: New York U P, 2007) 148.

2. "Generalissimo," 30 Rock. Robert Carlock. Dir. Todd Holland. NBC. (5 February 2009).

3. Survey respondent, email to the author, August 16, 2009.

4. Survey respondent, email to the author, August 25, 2009.

5. Charles J. Stivale, Gilles Deleuze's ABCs: The Folds of Friendship (Baltimore: Johns Hopkins U P, 2008) 35.

6. Atul Gawande, "Hellhole," The New Yorker 85:7, 30 March 2009, <www.newyorker.com/ reporting/2009/03/30/090330fa_fact_gawande>.

7. OED Online, v. "perform," <www.oed.com $>$.

8. For an account of the telenovela as a hybrid media form, see John Sinclair, Latin American Television: A Global View (New York: Oxford U P, 1999) 17. For an account of the ways in which earlier theories of cultural imperialism are being revised by scholars of transnationalism and global capitalism, see Ramaswami Harindranath, "Reviving 'Cultural Imperialism': International Audiences, Global Capitalism, and the Transnational Elite,” Planet TV: A Global Television Reader, ed. Lisa Parks and Shanti Kumar (New York: New York U P, 2003) 155-168.

9. Janice Radway, "What's the Matter with Reception Study? Some Thoughts on the Disciplinary Origins, Conceptual Constraints, and Persistent Viability of a Paradigm," New Directions in American Reception Study, ed. Philip Goldstein and James L. Machor (New York: Oxford U P, 2008) 343. 
10. Ien Ang, Watching Dallas: Soap Opera and the Melodramatic Imagination, trans. Della Couling (New York: Methuen, 1985) 11.

11. Lynne Joyrich, "Epistemology of the Console," Queer TV: Theories, Histories, Politics, ed. Glyn Davis and Gary Needham (New York: Routledge, 2009) 15-47.

12. See Anna McCarthy, Ambient Television: Visual Culture and Public Space (Durham: Duke U P, 2001) and, with Nick Couldry, "Introduction: Orientations: Mapping MediaSpace," MediaSpace: Place, Scale and Culture in a Media Age, ed. Couldry and McCarthy (New York: Routledge, 2004) 1-18; and Lisa Parks, Cultures in Orbit: Satellites and the Televisual (Durham: Duke U P, 2005), and "Where the Cable Ends: Television beyond Fringe Areas," Cable Visions: Television Beyond Broadcasting, ed. Sarah Banet-Weiser, Cynthia Chris, and Anthony Freitas (New York: New York U P, 2007) 103-126.

13. Gary R. Edgerton, "'Where the Past Comes Alive': Television, History, and Collective Memory," A Companion to Television, ed. Janet Wasko (Malden, MA: Blackwell Publishing, 2005) 366-67.

14. Couldry, "On the Set of The Sopranos" 142.

15. See, for instance, Anna McCarthy, Ambient Television; Lynn Spigel, Make Room for TV: Television and the Family Ideal in Postwar America (Chicago: U of Chicago P, 1992); and Amy Villarejo, Lesbian Rule: Cultural Criticism and the Value of Desire (Durham: Duke U P, 2003).

16. Amy Villarejo, "Ethereal Queer: Notes on Method," Queer TV, 58.

17. Misha Kavka, Reality Television, Affect and Intimacy: Reality Matters (New York: Palgrave Macmillan, 2008) 5, 13, 28.

18. OED Online, a. "intimate," <www.oed.com>.

19. Joseph Roach, It (Ann Arbor: U of Michigan P, 2007) 3.

20. David Wills, Prosthesis (Stanford, Stanford U P, 1995), 218.

21. Marquard Smith and Joanne Morra, "Introduction," The Prosthetic Impulse: From a Posthuman Present to a Biocultural Future, ed. Smith and Morra (Cambridge: MIT P, 2006) 4, 7, 11.

22. See Thomas Elsaesser, "Zapping One's Way into Quality: Arts Programmes on TV," Writing for the Medium: Television in Transition, ed. Elsaesser, Jan Simons, and Lucette Bronk (Amsterdam: Amsterdam U P, 1994) 54-63; and Jaap Kooijman, "Cruising the Channels: The Queerness of Zapping," Queer TV, 159-171.

23. Lauren Berlant, "Introduction: The Intimate Public Sphere," The Queen of America Goes to Washington City: Essays on Sex and Citizenship (Durham: Duke U P, 1997) 5, 9. See also Berlant, "Intimacy: A Special Issue," Intimacy, ed. Berlant (Chicago: U of Chicago P, 2000) 1-8.

24. Berlant, "The Theory of Infantile Citizenship," The Queen of America Goes to Washington City $39,42,51$.

25. Berlant, "Introduction: The Intimate Public Sphere," 11-12.

26. "Mr. Lisa Goes to Washington." The Simpsons. George Meyer. Dir. Wes Archer. FOX. 26 September 1991.

27. As dual inhabitants of what I am calling "domestic time/space" and "satirical time/space," the characters on The Simpsons are not unlike the characters in musical theatre, who, as Scott McMillin has persuasively argued, are split rather than coherent figures who move back and forth between "book time" and "lyric time," with the result that "the crackle of difference . . . can be felt between the book and the numbers, between the songs and dances, between dance and spoken dialogue." See McMillin, The Musical as Drama (Princeton: Princeton U P, 2006) 2-3.

28. "HOMR." The Simpsons. Al Jean. Dir. Mike B. Anderson. FOX. 7 January 2001).

29. See the entry for "HOMR" at The Simpsons Archive, <www.snpp.com/episodes/BABF22>.

30. Villarejo, "Ethereal Queer," 51-52, 49.

31. Nick Salvato, "Tramp Sensibility and the Afterlife of Showgirls," Theatre Journal 58.4 (Fall 2006): 642 .

32. Here I take a cue from Rick Altman's now-classic assertions that sound enjoys a primacy over image in the medium of television and that we must attend therefore to televisual sound, as well as from Glyn Davis's more recent investigation of the effects, "both aural and affective," of "TV's acousmêtres." See Altman, "Television/Sound," Studies in Entertainment: Critical Approaches to Mass Culture, ed. Tania Modleski (Bloomington and Indianapolis: Indiana U P, 1986) 39-54; and Davis, "Hearing Queerly: Television's Dissident Sonics," Queer TV 178.

33. "No Sex 'n' the City." Will \& Grace. By Steve Gabriel. Dir. James Burrows. NBC. 25 March 2004). 
34. Clive Thompson, "Brave New World of Digital Intimacy," The New York Times Magazine. 5 September 2008 <www.nytimes.com/2008/09/07/magazine/07awareness-t.html>. The Dunbar number represents the supposedly hard-wired, cognitive upper limit to the number of people with whom one can maintain intimate relationships.

35. Stivale, Gilles Deleuze's ABCs, 81, 132, 135.

36. 135 .

37. Gilles Deleuze, "Immanence: A Life," Pure Immanence: Essays on A Life, trans. Anne Boyman (New York: Zone Books, 2001) 29, 31, 27.

38. 29 , second and third emphases added.

39. Stivale, Gilles Deleuze's ABCs 135.

40. Deleuze, quoted in Stivale 132.

41. Deleuze, "Immanence: A Life" 28.

42. See Giorgio Agamben, Homo Sacer: Sovereign Power and Bare Life (Stanford: Stanford U P, 1998) 88.

43. Gawande, "Hellhole." 